\title{
Resenha
}

Educação e psicanálise.

Rinaldo Voltolini

Rio de Janeiro: Zahar, 2011, 84p.

\section{A PEDAGOGIA TOMADA PELO AVESSO}

\section{Flavia Vasconcellos}

[4 ducação e psicanálise é o título do livro de Rinaldo Voltolini, psicanalista e professor doutor da Faculdade de Educação da USP, lançado em 2011 pela editora Jorge Zahar, em sua coleção Passo-a -Passo. O objetivo da coleção é apresentar, de forma acessível e não muito extensa, assuntos considerados relevantes em seus diferentes campos de saber, oferecendo ao leitor chaves de leitura que embasem um ingresso não ingênuo nesse terreno de discussão.

Voltolini leva a sério essa incumbência, ao oferecer-nos um texto generoso, que evita os "dialetos" teóricos, buscando sempre clareza e objetividade em sua transmissão, a fim de criar um verdadeiro diálogo com o leitor. Sendo assim, seu livro cumpre uma dupla função: iniciar alguém nessa discussão e oferecer aos já "iniciados" um novo e fecundo viés de leitura.

Ao revisitar as preocupações e elaborações freudianas sobre o tema, à luz das contribuições de Lacan, reconstitui um eixo de discussão de extrema importância, que vai da noção do impossível do educar às condições de possibilidade da educação. Tomando a pedagogia pelo seu avesso, ou seja, pelo outro lado de um mesmo pano (p. 10), não irá discutir a boa relação pedagógica, mas sim apontar "a precariedade inevitável de todo ato educativo, sobre a ignorância

- Psicanalista. Fundadora e coordenadora do Grupo de Apoio à Escolarização Trapézio e mestre em Educação pela Faculdade de Educação da Universidade de São Paulo (FEUSP), São Paulo, SP, Brasil. 
particular e insuperável, embora não incontornável, de todo adulto em relação à criança.... e sobre o incerto caminho do sujeito ao longo de sua educação e dos múltiplos riscos de naufrágio nessa viagem” (pp. 10-11).

A aproximação dos campos da educação e da psicanálise não é recente; data do próprio tempo da elaboração freudiana a respeito de sua invenção. A despeito disso, suas implicações teórico-práticas, seu amadurecimento conceitual e seus destinos contam a história de uma longa querela marcada por esforços de cunho epistemológico em delinear as bordas de cada um desses campos, ora tomando-os como antinômicos e não aproximáveis, ora demonstrando junções e articulações possíveis, que não só não "ferem" a integridade e legitimidade de nenhum desses campos de saber, como tornam fértil seu encontro.

O livro de Voltolini recupera o lastro, as idiossincrasias e os impasses dessa aproximação, sem se deter em seus pontos de discórdia, mas buscando apontar seu impacto e relevância para a práxis pedagógica, tomando-a como uma discursividade que não se sobrepõe à educação, e que, a despeito de uma ambição de mestria que lhe é inerente, encontra na instabilidade e no incerto sua fiel e inseparável comitiva.

Para tanto, atravessa um primeiro momento de discussão sobre temas que herdamos de Freud em seu encontro com a educação, como o impos-

418 Estilos clin., São Paulo, v. 18, n. 2, mai./ago. 2013, 417-421. 
sivel da educação e o fazer crescer, e sobre os embaraços do educar, discutindo o problema do conbecimento sobre a criança. Nesse percurso, faz um mapeamento dos ensaios de Freud sobre a questão da educação, oferecendo um importante guia para o leitor interessado em se aprofundar nessa discussão; para concluir, aponta incidências do ensino de Lacan sobre o tema.

Acompanhamos, com o autor, como os possíveis do educar se abrem somente a partir do reconhecimento de seu impossível. Prontamente, Voltolini nos alerta para o fato de que o impossível do educar não está referido a um inexequível ou às mazelas de um sistema educativo. Antes disso, tratase de um inalcançável estrutural, que diz respeito à tentativa de fazer que se sobreponham duas dimensões, a do simbólico e a do real (p. 25).

A educação, sendo um dos ofícios impossíveis, está submetida à ação de um ideal: aparelhar devida e definitivamente uma criança para os imprevistos da vida. Justamente por isso, a criança se vê fadada a uma inevitável decepção, já que os resultados alcançados jamais poderão recobrir completamente aqueles que foram almejados de início.

Soma-se a esse atravessamento do ideal o fato de que se trata de um campo necessariamente mediado pela palavra, e esta não é exata nem justa: a palavra foi feita menos para informar, e mais para evocar. "Em todo ato de fala há uma dupla emissão" (p. 36), a palavra evocada em um enunciado sempre portará um a mais de sentido que é transmitido à revelia de nossa vontade (p. 36), e, sendo assim, jamais nos é possível prever exatamente o efeito de um dizer sobre uma outra pessoa.

No terreno dos impossíveis, temos de lidar com a falta de controle, e também inventar meios para enfrentar o desejo narcísico de negar os limites, desejo esse que tende a se guiar por uma ambição de totalização.

O discurso pedagógico contemporâneo está marcado pelo esforço "de organizar um ato cientificamente balizado" (p. 72), promovendo com isso uma perniciosa exclusão do sujeito. Tal ambição comparece tanto nas tentativas, bastante atuais, de se "esvaziar o espaço da subjetividade do professor, reservando-lhe um lugar abstrato de mediador entre o aluno e o objeto de conhecimento" (p. 32), como também no equívoco que faz crer ao adulto contemporâneo que este possa não influenciar nossas crianças.

Educar, lembra-nos o autor, é uma prática fundamentalmente decisória, atrelada a uma situação dilemática: não sendo guiada por nenhuma verdade, ela tem de lidar com a dúvida e a incerteza que decorrem do fato de não haver conciliação possível entre opostos. Recupera de Freud, a bela imagem sobre o desafio do educador: a do navegador que, para manter-se em sua rota, precisa driblar tempestades e perigos, e cuidar para não se aproximar demais dos monstros Cila 
e Caribde, os quais estão posicionados em lugares opostos e oferecem perigos diferentes, mas igualmente temíveis. A pedagogia está submetida a essa dinâmica dilemática que é, na verdade, inerente à experiência humana: quando fazemos uma escolha, estamos sempre no risco de nos arrependermos. Mas não escolher não é possível, afinal a não escolha é uma escolha!

Outra marca do discurso pedagógico contemporâneo é o desejo de saber mais e mais sobre a criança, com a ambição de que esse conhecimento, cientificamente qualificado, possa embasar um saberfazer ou uma ação pedagógica justa, precisa e exitosa. A ignorância do adulto sobre a criança, no entanto, não está referida a uma falta de conhecimento sobre ela, mas sim à ação do recalque, que torna esquecida a criança que todo adulto foi. E a criança, agora no lugar de estrangeiro, lembra ao adulto que é possível agir com mais liberdade em relação a seu desejo e àquilo que lhe dá prazer. $\mathrm{O}$ excesso de repressão de um adulto sobre uma criança revela a hostilidade que lhe desperta a lembrança dessa criança que ele foi (pp. 42-43). Examinando a palavra compreender, Voltolini nos faz ver um aspecto desse significante que aponta para um aprisionamento e apagamento do outro (p. 44). Paradoxalmente, quanto mais ele responder a essa ambição de um saber universal sobre a criança, mais distante estará dela. Para Freud, a única saída possível para esse paradoxo não se dará pela via do conhecimento, mas sim pela via do participar de sua vida (p. 45).

Toda educação está comprometida com a tarefa de fazer crescer uma criança, de dar-lhe condições de acesso ao mundo adulto, tarefa essa que equivale ao próprio processo civilizatório. Tais condições, longe de se confundirem com os hoje tão difundidos instrumentos e habilidades, apontam para as condições do desejo, por um lado, e do compartilhamento, por outro. Condições de processamento do humano que não se desenvolvem naturalmente, mas que dependem de um processo de hominização, pelo qual um pequeno rebento se faz propriamente humano. Hominizar é estabelecer condições compartilháveis, às quais a criança deve, num primeiro momento, alienar-se para, apenas ulteriormente, poder se separar (p. 70).

Em "O futuro de uma ilusão", de 1927, Freud propõe a ideia de educar para a realidade, que não apenas porta o compromisso da educação com o coletivo, de certa adaptação que permita um compartilhamento, como também aponta para a ideia de educar para a realidade do desejo, o que significa "favorecer o progresso do trabalho das pulsões de vida" (p. 59), um respeito à verdade do 
sujeito, a despeito da exigência de enquadre que a vida gregária nos impõe.

Para concluir, valendo-se da contribuição lacaniana da análise dos discursos elaborada em O seminário, livro 1: o avesso da psicanálise, Voltolini trabalha sobre a torção dos campos do conhecimento "a educação" e "a psicanálise" para os discursos "educar" e "psicanalisar". É esse gesto que permitirá ao autor dar um passo além da genuína preocupação epistemológica por demarcar fronteiras. Os discursos se constituem como um instrumento de leitura que torna mais nítidos seus pontos de inexorável encontro, bem como suas diferenças estruturais.

Assim, Educação e psicanálise, de Rinaldo Voltolini, oferece ao leitor coordenadas para se guiar nesse campo, revela e discute seus pontos sensíveis e, assim, aponta direções de incursão e de intervenção que enaltecem as invenções e o improviso, e tornam o impossível do educar um fértil e insondável terreno de possíveis. 